\title{
Free Cash Flow, Corporate Social Responsibility and Enterprise Value: An Empirical Analysis Based on Listed High-tech Enterprises
}

\author{
Dan Han, Xuemei Chen* \\ School of International Business, Shanxi Normal University \\ Xi'an City, China
}

\begin{abstract}
For companies and managers, corporate value has always been the focus. However, whether the traditional research results are suitable for high-tech enterprises remains to be discussed. After all, high-tech companies have some unique features. If high-tech companies do not see this clearly and blindly adopt common practices to enhance corporate value, the results obtained may not meet their expectations. So this paper uses the balanced panel data of listed companies which were identified as high-tech enterprises in 2008 to explore the relationship among listed high-tech companies' social responsibility, free cash flow, and corporate value. The results of our research show that there is a positive correlation between the free cash flow and the corporate value of listed high-tech companies; the listed high-tech companies' commitment to social responsibility will reduce their corporate value.
\end{abstract}

Keywords-Corporate social responsibility; Free cash flow; Enterprise Value; High-tech companies

\section{INTRODUCTION}

High-tech companies, as emerging industries, derive most of their value from the growth potential of future businesses. Their premium in the capital market reflects their ability to introduce new products through R\&D. Only by continuously investing in intangible assets can the company maintain its dynamic competitive advantage. The continuous research and development of new technologies requires large amounts of cash. Therefore, for high-tech companies, the impact of free cash flow on the corporate value worth exploring. At the same time, Listed high-tech companies have always been watching by the public and the government, but will it be possible to increase enterprise value by assuming social responsibility in order to meet the public?

\section{THEORETICAL ANALYSIS AND RESEARCH HYPOTHESIS}

According to Jensen's (1986) theory about "free cash flow hypothesis", when companies have a large amount of free cash, Managers prefer to invest in less efficient projects to paying to shareholders, and the result is to reduce the value of the company [1] .However, there is no doubt that the value of the enterprise is mainly determined by its future profitability and not by the amount of existing assets. Therefore, for high-tech enterprises with few tangible assets but a relatively large proportion of intangible assets, their free cash Traffic is more likely to be the driving force behind the growth of its corporate value. We therefore propose the following hypothesis:

The main hypothesis 1(H1): There is a significant correlation between free cash flow and enterprise value.

More and more companies are aware of the necessity and importance of undertaking Corporate Social Responsibility (CSR), and they are actively involved in it. However, how do companies balance shareholder value creation and social responsibility under resource constraints? Whether the implementation of CSR can create value for the enterprise? These are the issues that managers and investors care about and the controversy in the theoretical community. Peloza (2009) [2] reviewed the previous literature and found that some studies show that CSR can improve the financial performance or stock value of the company, but Some studies have shown that there is relation or have a negative correlation between CSR and enterprise value.For example, Preston and Banno (1997) [3] studied the negative synergy between the CSR and firm value. They point out that when managers seek to maximize their own interests, they will reduce the cost of fulfilling their social responsibilities to achieve a higher level of corporate performance, which will ultimately affect the value of the company.

We believe that assuming social responsibility will increase the company's additional expenditures, and these expenditures do not belong to the company's daily business activities, it will not bring direct economic benefits to the company. In light of the above-mentioned studies, we formulate the following hypothesis: 
The main hypothesis 2(H2): For listed high-tech companies, assuming social responsibility will reduce their corporate value.

\section{Theoretical Method,Model SElection AND DATA SOURCES}

\section{A. Research sample and data}

Our original data comes from 56 listed companies that were identified as high-tech companies in 2008. After eliminating three companies (ST) and one delisting companies in the later period, we choose 52 listed high-tech companies as our sample. Because in 2008, our country began to require some listed companies to disclose social responsibility information, we take 2008 as the starting year. We collected the corporate social responsibility and financial data of these 52 companies between 2008 and 2016, and then we get a total of 468 sample data. Among them, the list of high-tech enterprises comes from the RESSET database; corporate social responsibility data and corporate value data come from the CSMAR database; and other data come from the WIND database.

\section{B. Variable construction}

\section{1) Dependent variable:Enterprise Value}

The purpose of this paper is to test the impact of free cash flow of high-tech enterprises on the value of the company. Because this influence has a certain lag, and accounting indicators such as financial performance can hardly reflect the long-term value of the company, we suggest that using use the natural logarithm of TobinQ which can better reflect the true value of the company as an alternative variable to corporate value.

2) Independent Variable:Free cash flow and corporate social responsibility

The free cash flow (FCF) of Corporate refers to the total cash flow owned by all investors of an enterprise, including shareholders and creditors. In order to truly reflect the value of the company, we has amended the free cash flow of the company by dividing it by the operating income of the company, then use this relative indicator to explain the value of the company.

As for the degree of corporate social responsibility (CSRQUA), the theoretical community has always lacked a unified and authoritative measure. According to the stakeholder theory, the definition of corporate social responsibility is based on the relationship between the company and its stakeholders. As long as the needs of stakeholders are met, the company assumes social responsibility (Clarkson, 1995).Therefore, we have selected 12 aspects from the sub-bank of social responsibility research of the CSMAR database as the basic standard for measuring corporate social responsibility commitment. We assign 0 to 1 to each aspect, for example, when the firm assumes the social responsibility in this aspect, we assign the value as 1 , otherwise it is 0 . Then, we add up these 12 aspects of the score, and divide by 12 to get the standardization to get the score of CSRQUA.

\section{CSRQUA $=$ sum of the scores $/ 12$}

\section{3) Variables Control}

In addition to the two independent variables above, there are some other variables that may affect the company value. We, thus, add some other variables in our models.

Some researchers have shown that firm size can have a significant influence on enterprise value. So In our study, similar to Hull and Rothenberg (2008), we measure the size of the firm (SIZE) as the natural logarithm of the total assets [4].

The debt level is the second control variable that we use in our research. It is a risk indicator for people and can have a significant effect on enterprise value. Because of this influence, we take the level of debt into account. In this paper, Refer to articles by many authors (Aras et al.2010; Flammer, 2013), the level of debts (DEBT) is measured as: total debt/total assets [5].

As the third control variable in our study, ROA is used to show the financial performance. Thus, the return on assets (ROA) can measured as income before extraordinary items divided by total assets.

In addition, we also refer to the approach of Bing Zhou (2016), adding the shareholding ratio of the largest shareholder (FIRST) and the company's growth rate of operating income (GROWTH) as control variables [6].These variables are used to control some of the company's basic characteristics. The existing literature finds that these factors will affect the value of the company, but the specific relationship between these factors and the company's value is often reflected by different research problems. Therefore, we did not predict the regression of the above variables. Meanwhile, we also control for industry and year fixed effects in the model.

\section{Empirical Model}

In order to test the hypothesis of the effect of FCF and CSRQUA on enterprise value, we used the panel data to build the following model:

$$
\begin{aligned}
& \ln \text { Tobin }_{\mathrm{i}, t}=\alpha_{1}+\beta_{1} F C F_{i, t}+\beta_{2} \operatorname{SIZE}_{i, t}+\beta_{3} D E B T_{i, t}+\beta_{4} \text { ROA }_{i, t}+\beta_{5} \text { FIRST }_{i, t} \\
& +\beta_{6} \text { GROWTH }_{i, t}+\text { IndustryIn dicator } \mathrm{s}+\text { YearIndica tors }+\varepsilon_{i, t} \\
& \ln \text { Tobin }_{\mathrm{i}, t}=\alpha_{2}+\beta_{7} \operatorname{CSRQUA}_{\mathrm{i}, t}+\beta_{8} \operatorname{SIZE}_{\mathrm{i}, t}+\beta_{9} \text { DEBT }_{\mathrm{i}, t}+\beta_{10} \operatorname{ROA}_{\mathrm{i}, t}+\beta_{11} \text { FIRST }_{\mathrm{i}, t} \\
& +\beta_{12} \text { GROWTH }_{\mathrm{i}, t}+\text { IndustryIn dicator } \mathrm{s}+\text { YearIndica tors }+\varepsilon_{\mathrm{i}, t}
\end{aligned}
$$




\section{EMPIRICAL RESULT}

\section{A. Descriptive statistics}

From Table 1, we can see that the average value of social responsibility of listed high-tech companies is 0.6954 , which shows that listed companies that were identified as high-tech enterprises in 2008 assumed more social responsibilities between 2008 and 2016. The average free cash flow of the company is -0.0377 , and the difference between the maximum and minimum values is as high as 3.2 , indicating that there is a significant difference in the level of free cash flow among listed high-tech companies. The average value of lnTobinQ is 0.6274 , the standard deviation is 0.7713 and the range difference is 4.3737. Overall, there is a big difference in the company value of different listed high-tech companies, and it also reflects that there is a certain imbalance in the development level of the company.

TABLE I. DESCRIPTIVE STATISTICS

\begin{tabular}{|c|c|c|c|c|c|}
\hline Variable & Obs & Mean & Std.Dev. & Min & Max \\
\hline 1nTobinQ & 465 & .6274247 & .771393 & -1.687199 & 2.686477 \\
\hline FCF & 468 & -.0377195 & .239898 & -2.312677 & .8996524 \\
\hline CSRQUA & 339 & .6954277 & .1024257 & .4166667 & .9166667 \\
\hline SIZE & 468 & 3.614869 & 1.303205 & .8554631 & 7.508621 \\
\hline DEBT & 468 & .4319618 & .2004725 & .0377912 & .9785692 \\
\hline ROA & 468 & 7.631497 & 7.466194 & -17.6839 & 58.6342 \\
\hline GROWTH & 468 & -454.4652 & 11035.23 & -235274.9 & 37732.82 \\
\hline FIRST & 468 & 36.47643 & 13.59158 & 6.8 & 73.87 \\
\hline
\end{tabular}

\section{B. Correlation Analysis}

Table 2 shows the correlation coefficients between variables. The pearson correlation coefficient test shows that the absolute value of the pearson correlation coefficient between the independent variable and the control variable does not exceed 0.1, except for FIRST and GROWYH, which indicating that the multicollinearity is effectively controlled. Therefore, it is still necessary to control the variables above.

TABLE II. COVARIANCE MATRIX COEFFICIENTS OF XTREG MODEL

\begin{tabular}{|c|c|c|c|c|c|c|c|c|}
\hline $\mathrm{e}(\mathrm{v})$ & $\mathrm{FCF}$ & CSRQUA & SIZE & DEBT & ROA & GROWTH & FIRST & cons \\
\hline FCF & .01449041 & & & & & & & \\
\hline CSRQUA & .0089437 & .05981118 & & & & & & \\
\hline SIZE & .00043194 & - & .0004445 & & & & & \\
\hline DEBT & -.00562166 & $\begin{array}{c}.00024792 \\
- \\
.02186898\end{array}$ & -.00108958 & .0623861 & & & & \\
\hline ROA & .00007523 & .00015787 & .00001279 & .00004102 & .00001826 & & & \\
\hline GROWTH & $-2.129 \mathrm{e}-08$ & $\begin{array}{c}3.0793 \mathrm{e}- \\
07\end{array}$ & $-2.756 e-09$ & $-1.399 \mathrm{e}-08$ & $7.912 \mathrm{e}-10$ & $8.618 \mathrm{e}-12$ & & \\
\hline FIRST & -.00011713 & $\begin{array}{c}- \\
.00021063\end{array}$ & $-3.584 \mathrm{e}-06$ & $4.802 \mathrm{e}-06$ & $-8.108 \mathrm{e}-07$ & $2.049 \mathrm{e}-09$ & .0000179 & \\
\hline $\begin{array}{l}\text { _cons } \\
\text { ccons }\end{array}$ & .00100371 & $\begin{array}{c}- \\
.02379357 \\
\end{array}$ & -.0002249 & $\begin{array}{c}- \\
.00631758 \\
\end{array}$ & $\begin{array}{c}- \\
.00028108 \\
\end{array}$ & $-2.746 e-07$ & -.00050547 & $\begin{array}{c}.0412682 \\
2 \\
\end{array}$ \\
\hline
\end{tabular}

\section{Regression analysis}

Table 3 and Table 4 reports the results of the balanced panel regression. The result of the F-test is to reject the establishment of a hybrid model (OLS). Therefore, we should choose a fixed effect model or a random effects model. And the result of the Hausman test rejects the null hypothesis. So we should establish a fixed effect model. When we use balancing panel data, logarithmic processing was performed on individual variables to control possible problem of heteroscedasticity.
The first Model tests the impact of free cash flow of listed high-tech companies on corporate value. The regression coefficient of corporate free cash flow is positive, and there is a significant positive correlation between corporate free cash flow and corporate value at the 5\% confidence interval. It shows that the free cash flow for high-tech companies can promote the value of the company to a certain extent. However, the regression coefficient of corporate free cash flow is between 0.223 and 0.244 , which indicates that the positive free-cash flow effect of the company on corporate value is not significant. 
TABLE III. THE REGRESSION RESULT OF H1

\begin{tabular}{|c|c|c|c|c|c|}
\hline & $\begin{array}{c}(1) \\
\text { OLS_Model1 } \\
\end{array}$ & $\begin{array}{c}(2) \\
\text { FE_robust_Model1 }\end{array}$ & $\begin{array}{c}(3) \\
\text { FE_Model1 }\end{array}$ & $\begin{array}{c}\text { (4) } \\
\text { RE_robust_Model1 }\end{array}$ & $\begin{array}{c}(5) \\
\text { RE_Model1 } \\
\end{array}$ \\
\hline FCF & $\begin{array}{c}0.223^{*} \\
(0.0959)\end{array}$ & $\begin{array}{l}0.244^{*} \\
(0.101)\end{array}$ & $\begin{array}{c}0.244^{*} \\
(0.0975)\end{array}$ & $\begin{array}{c}0.223^{*} \\
(0.0959)\end{array}$ & $\begin{array}{c}0.223^{*} \\
(0.0979)\end{array}$ \\
\hline SIZE & $\begin{array}{c}-0.210^{* * * *} \\
(0.0383)\end{array}$ & $\begin{array}{l}-0.176^{* *} \\
(0.0505)\end{array}$ & $\begin{array}{c}-0.176 * * * \\
(0.0410)\end{array}$ & $\begin{array}{l}-0.210 * * * \\
(0.0383)\end{array}$ & $\begin{array}{c}-0.210^{* * * *} \\
(0.0291)\end{array}$ \\
\hline DEBT & $\begin{array}{l}-1.068 * * * \\
(0.231)\end{array}$ & $\begin{array}{l}-0.567 \\
(0.345)\end{array}$ & $\begin{array}{l}-0.567 * \\
(0.256)\end{array}$ & $\begin{array}{c}-1.068 * * * \\
(0.231)\end{array}$ & $\begin{array}{c}-1.068 * * * \\
(0.190)\end{array}$ \\
\hline ROA & $\begin{array}{l}0.0187 * * * \\
(0.00447)\end{array}$ & $\begin{array}{l}0.0137 * \\
(0.00534)\end{array}$ & $\begin{array}{r}0.0137 * * * \\
(0.00362)\end{array}$ & $\begin{array}{c}0.0187 * * * \\
(0.00447)\end{array}$ & $\begin{array}{r}0.0187 * * * \\
(0.00352)\end{array}$ \\
\hline GROWTH & $\begin{array}{l}-0.000000274 \\
(0.000000333)\end{array}$ & $\begin{array}{l}-0.000000950^{*} \\
(0.000000359)\end{array}$ & $\begin{array}{l}-0.000000950 \\
(0.000000359)\end{array}$ & $\begin{array}{l}-0.000000274 \\
(0.000000333)\end{array}$ & $\begin{array}{l}-0.000000274 \\
(0.00000203)\end{array}$ \\
\hline FIRST & $\begin{array}{l}-0.00393 \\
(0.00356)\end{array}$ & $\begin{array}{l}0.000552 \\
(0.00483)\end{array}$ & $\begin{array}{l}0.000552 \\
(0.00411)\end{array}$ & $\begin{array}{l}-0.00393 \\
(0.00356)\end{array}$ & $\begin{array}{l}-0.00393 \\
(0.00256)\end{array}$ \\
\hline _cons & $\begin{array}{c}1.859 * * * \\
(0.165)\end{array}$ & $\begin{array}{c}1.395 * * * \\
(0.210)\end{array}$ & $\begin{array}{c}1.395 * * * \\
(0.224)\end{array}$ & $\begin{array}{c}1.859 * * * \\
(0.165)\end{array}$ & $\begin{array}{c}1.859 * * * \\
(0.133)\end{array}$ \\
\hline $\mathrm{N}$ & 465 & 465 & 465 & 465 & 465 \\
\hline R-sq & 0.1213 & 0.1279 & 0.1279 & 0.1213 & 0.1213 \\
\hline
\end{tabular}

The second model examined the impact of corporate social responsibility on corporate value. The regression coefficient for corporate social responsibility was -0.71 , and it was significantly negatively related to corporate value at a $1 \%$ confidence level. This shows that the excessive performance of high-tech enterprises in social responsibility does not significantly promote the value of the company, but will reduce the value of the enterprise.

TABLE IV. THE REGRESSION RESULT OF H2

\begin{tabular}{|c|c|c|c|c|c|}
\hline & $\begin{array}{c}(1) \\
\text { OLS_Model2 }\end{array}$ & $\begin{array}{c}\text { (2) } \\
\text { FE_robust_Model2 }\end{array}$ & $\begin{array}{r}(3) \\
\text { FE_Model2 }\end{array}$ & $\begin{array}{c}(4) \\
\text { RE_robust_Model2 }\end{array}$ & $\begin{array}{c}(5) \\
\text { RE_Model2 }\end{array}$ \\
\hline CSRQUA & $\begin{array}{c}-0.711 * * \\
(0.243)\end{array}$ & $\begin{array}{c}-0.719 * * \\
(0.255)\end{array}$ & $\begin{array}{c}-0.719^{*} \\
(0.274)\end{array}$ & $\begin{array}{c}-0.711^{* *} \\
(0.243)\end{array}$ & $\begin{array}{c}-0.711^{* *} \\
(0.264)\end{array}$ \\
\hline SIZE & $\begin{array}{c}-0.219 * * * \\
(0.0426)\end{array}$ & $\begin{array}{c}-0.263 * * * \\
(0.0591)\end{array}$ & $\begin{array}{c}-0.263 * * * \\
(0.0552)\end{array}$ & $\begin{array}{l}-0.219 * * * \\
(0.0426)\end{array}$ & $\begin{array}{c}-0.219 * * * \\
(0.0352)\end{array}$ \\
\hline DEBT & $\begin{array}{c}-1.159 * * * \\
(0.325)\end{array}$ & $\begin{array}{l}-0.641 \\
(0.486)\end{array}$ & $\begin{array}{l}-0.641 \\
(0.329)\end{array}$ & $\begin{array}{c}-1.159 * * * \\
(0.325)\end{array}$ & $\begin{array}{c}-1.159 * * * \\
(0.248)\end{array}$ \\
\hline ROA & $\begin{array}{l}0.0169 * * \\
(0.00520)\end{array}$ & $\begin{array}{c}0.0149 * \\
(0.00571)\end{array}$ & $\begin{array}{c}0.0149 * \\
(0.00447)\end{array}$ & $\begin{array}{l}0.0169 * * \\
(0.00520)\end{array}$ & $\begin{array}{l}0.0169 * * * \\
(0.00410)\end{array}$ \\
\hline GROWTH & $\begin{array}{c}-0.00000500^{*} \\
(0.00000237)\end{array}$ & $\begin{array}{c}-0.00000550^{*} \\
(0.00000252)\end{array}$ & $\begin{array}{l}-0.00000550 \\
(0.0000117)\end{array}$ & $\begin{array}{l}-0.00000500^{*} \\
(0.00000237)\end{array}$ & $\begin{array}{r}-0.00000500 \\
(0.0000115)\end{array}$ \\
\hline FIRST & $\begin{array}{l}-0.00672 \\
(0.00407)\end{array}$ & $\begin{array}{l}-0.00960 \\
(0.00826)\end{array}$ & $\begin{array}{l}-0.00960 \\
(0.00622)\end{array}$ & $\begin{array}{l}-0.00672 \\
(0.00407)\end{array}$ & $\begin{array}{l}-0.00672 \\
(0.00346)\end{array}$ \\
\hline _cons & $\begin{array}{l}2.487 * * * \\
(0.204)\end{array}$ & $\begin{array}{c}2.591 * * * \\
(0.380)\end{array}$ & $\begin{array}{l}2.591 * * * \\
(0.416)\end{array}$ & $\begin{array}{c}2.487 * * * \\
(0.204)\end{array}$ & $\begin{array}{c}2.487 * * * \\
(0.261)\end{array}$ \\
\hline $\mathrm{N}$ & 338 & 338 & 338 & 338 & 338 \\
\hline R-sq & 0.1652 & 0.1729 & 0.1729 & 0.1652 & 0.1652 \\
\hline
\end{tabular}


As for the other variables of the two models, the relationship between FIRST and corporate value is not significant, indicating that the current operating profit growth rate does not directly affect the market value of the enterprise. There is also a negative correlation between the DEBT and the company value, but the ROA is positively correlated with the value of the company, indicating that the company's value is concerned with the company's ability to obtain returns.

\section{CONCLUSIONS}

Today, Value Based Management (VBM) is getting more and more attention. It is an indisputable fact that the value of a company is regarded as the goal of modern corporate finance. It is the wisest choice for companies to implement this financial management goal and implement value management. Therefore, according to the characteristics of high-tech enterprises and the special value of high-tech enterprises, it is particularly necessary to re-analysis the value-driven factors of high-tech companies and to explore the factors that influence the value of high-tech companies from the perspective of value management.

Through empirical analysis, the following conclusions have been drawn:

First of all, high-tech enterprises can, according to their own actual conditions, not only invest in research and development and increase the proportion of intangible assets, but also retain part of the free cash flow, and cannot blindly occupy all funds.

Secondly, high-tech enterprises should first pay attention to their own development and actively promote the industrialization of innovation results. If they want to improve their own capabilities and corporate value, it is not recommended that they undertake large amounts of corporate social responsibility from the outset.
In short, when high-tech enterprises undertake social responsibilities, they must also pay attention to their own development and retain appropriate corporate free cash flow. This will help improve corporate value.

\section{ACKNOWLEDGEMENT}

This research was financially supported by research on the integration and innovation development mechanism of finance and cultural industry Project of National social science foundation youth program, China, Project Number :12CJL032;Humanities and Social Sciences Research Plan Fund Project of Education Ministry, Project Number:15YJA630052; Fundamental Research Funds of Central Universities of Shaanxi Normal University, Project Number: 10SZYB26.

\section{REFERENCES}

[1] Jensen M C. Agency Costs of Free Cash Flow, Corporate Finance, and Takeovers. American Economic Review, 2001, 76(2):323-329.

[2] Peloza, John, "The challenge of measuring financial impacts from investments in corporate social performance." Journal of Management, no.35, 2009, pp.1518-1541.

[3] Preston L E, Banno D P.The Corporate Social Financial Performance. Relationship: A Typology and Analysis. Business and Society, 1997 36(12):419-429.

[4] Hull, C.E.,\& Rothenberg,S.Firm performance: The interactions of corporate social performance with innovation and industry differentiation. Strategic Management Journal, 2008, 29(7), 781-789.

[5] Flammer, C.Corporate social responsibility and shareholder reaction: environmental awareness of investors. Academy of Management Journal, 2013, 56(3), 758-781.

[6] Bing Zhou, Hui Xu, Zhengliang Ren. Corporate social responsibility, free cash flow, and Corporate Value-Empirical research based on mediating effect. East China Economic Management, 2016, (2), 129-135. (In Chinese) 